\author{
Ewa Maria Kocój \\ ewa.kocoj@uj.edu.pl \\ Instytut Kultury \\ Wydział Zarządzania i Komunikacji Społecznej \\ Uniwersytet Jagielloński
}

\title{
Sacrum i przestrzeń. Hierotopia wyspy Kefalonia (wstępne rezultaty badania pilotażowego)
}

\section{Sacrum and Space. Hierotopy of Cephalonia Island (Preliminary Results of the Pilot Study)}

\begin{abstract}
Streszczenie: Bizantyńskie i post-bizantyńskie dziedzictwo kulturowe wysp i półwyspów greckich stanowi wciąż dla większości Europejczyków swoistą białą kartę. W obszarze studiów naukowych tylko nielicznych uczonych spoza Grecji znajdują się artefakty, jak również to, co mogłoby zostać zaliczone do tzw. niematerialnego dziedzictwa kulturowego ludzkości. Celem badań było poznanie hierotopii dziedzictwa kulturowego (religijnego) Kefalonii. Interesowała mnie odpowiedź na pytanie, czy na wyspie znajdują się przestrzenie hierofaniczne i hierotopiczne, nasycone w wyobrażeniach mieszkańców wyspy specjalną mocą i wynikającą z nich specjalną kreacją. Poszukiwałam wierzeń dotyczących powstawania tych miejsc, niezwykłych wydarzeń czy też świętych postaci z nimi związanych oraz organizacji przestrzeni w miejscach kultu religijnego Kefalończyków.

W artykule wykorzystane zostały wyniki badań naukowych prowadzonych z wykorzystaniem technik jakościowych stosowanych w podejściu emicznym (swobodny wywiad, jawna i niejawna obserwacja uczestnicząca, dokumentacja fotograficzna oraz analiza materiałów wizualnych). Badania opierały się również na historycznych i etnograficznych źródłach zastanych oraz na materiałach dostępnych w Internecie. Pokazały one, że w wyobraźni religijnej Kefalończyków ważną rolę odgrywają wyspiarski charakter regionu i obecność żywiołów: morze otaczające ląd i trzęsienia ziemi cyklicznie nawiedzające wyspę. To specyficzne warunki naturalne dały początek lokalnym legendom i hierotypicznym kreacjom miejscom kultu religijnego. Miały też wpływ na wykreowanie panteonu świętych postaci czuwających nad wyspą, których obecność podkreślana jest poprzez specyficzną hiereotopię miejsc kultu religijnego.
\end{abstract}

Słowa kluczowe: dziedzictwo kulturowe, przestrzeń kulturowa, święte miejsca, hierotopia, Kefalonia, Grecja, materialne i niematerialne dziedzictwo kulturowe, religijność prawosławna

Summary: The Byzantine and post-Byzantine cultural heritage of Greek islands and peninsulas is still a blank slate for most Europeans. Only a few scholars from outside Greece focus their scientific studies on artefacts and anything which could be considered as so-called intangible cultural heritage of the humanity. The objective of the study was to investigate the hierotopy of the religious heritage of Cephalonia. I was interested in whether the island has hierotopic spaces, saturated with special power and the resulting special creation in the islanders' minds. I searched for the beliefs about the origins of these places, extraordinary events, or the related sacred figures and organizations of spaces in the places used by Cephalonians for religious worship. 


\begin{abstract}
The article uses qualitative methods of scientific research applied from the emic perspectives (free interviews, explicit and implicit participatory observation, photographic documentation and analysis of visual material). The research also focused on the secondary (historic and ethnographic) sources as well as on resources available on the Internet.

The study has shown that an important role in Cephalonians' religious imagination is played by the insular nature of the region and the elements: the sea surrounding the land and the earthquakes which cyclically strike the island. These specific natural conditions have given birth to local legends and hierotopic creations of places of religious worship. They have formed the pantheon of the holy figures, whose presence is emphasized by the specific hierotopy of the places of religious worship built on the island.
\end{abstract}

Key words: cultural heritage, cultural space, sacred places, hierotopy, Cephalonia, Greece, tangible and intangible cultural heritage, Orthodox religiousness

Translated by Author

\title{
Wprowadzenie
}

Bizantyńskie dziedzictwo kulturowe wysp i półwyspów greckich stanowi dla większości Europejczyków swoistą białą kartę. Tylko nieliczni uczeni spoza Grecji zajmują się w swoich badaniach artefaktami i tym, co mogłoby zostać zaliczone do tzw. niematerialnego dziedzictwa kulturowego ludzkości tego regionu: wierzeniami, obrzędami, rytuałami, starymi profesjami itp. Tymczasem podróż przez wyspy i półwyspy greckie potrafi być wspaniałym źródłem inspiracji badawczej, można tu bowiem spotkać mające bardzo dużą wartość obiekty dziedzictwa kulturowego, m.in. stare prawosławne cerkiewki i przydrożne kapliczki (często w stanie ruiny), polichromie nieznanych malarzy czy ikony pisane przez wielkich (znanych i nieznanych) artystów świata greckiego. Uważny badacz dostrzeże też istnienie wierzeń, zwyczajów i obrzędów, których wątki i motywy sięgają korzeniami archaicznych tradycji (kreacja elementów przestrzeni na sanktuaria postaci znanych z mitologii greckiej, wiara w magiczną moc przedmiotów, wierzenia mówiące o przejawianiu się bóstw pod postacią żywiołów). Dawne zawody i rzemiosła wciąż są wykonywane przez mistrzów przekazujących z pokolenia na pokolenie techniki i tajemnice swojego fachu (np. Turcy wyplatający wiklinowe kosze i rozwożący je po różnych zakątkach wysp, kowale, romscy złomiarze gromadzący metalowe odpady, greccy rolnicy podróżujący samochodami i donośnymi głosami zachwalający swe ekologiczne gospodarstwa, pasterze wypasający owce i osły, pędzący swoje stada przez brzegi morza i wysokie góry, malarze ikon pielęgnujący tajniki swojej pracy). Bogaty i sięgający wielu stuleci wstecz dorobek kulturowy Greków, niemieszczący się w oficjalnym „dziedzictwie mainstreamowym”1, bywa rzadko prezentowany

\footnotetext{
${ }^{1}$ Pod pojęciem „dziedzictwo mainstreamowe” rozumiem materialne i niematerialne dziedzictwo kulturowe z tzw. głównego nurtu, które jest szeroko dostępne, uznawane za najwartościowsze i najbardziej reprezentatywne przez grupy większościowe w danym społeczeństwie i/lub przez większość członków grup
} 
i dyskutowany w większym międzynarodowym gronie naukowców. Sprawia to, że poza obszarem naukowego poznania znajduje się nadal wiele artefaktów i zjawisk składających się na tę kulturę, co uniemożliwia prowadzenie szeroko zakrojonych badań porównawczych.

Dostrzegłszy bogactwo kultury greckich wysp, podjęłam w sierpniu 2015 roku wstępne pilotażowe etnograficzne badania terenowe dotyczące dziedzictwa kulturowego Ke-

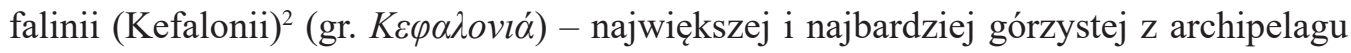
Wysp Jońskich. Wyspa licząca około 760 kilometrów kwadratowych powierzchni i 14 kilometrów szerokości, słynna z nawiedzających ją cyklicznie trzęsień ziemi, zasiedlona jest obecnie przez ponad 35 tysięcy mieszkańców, w większości Greków, z których część zamieszkuje naprzemiennie zarówno na kontynencie, jak i na wyspie ${ }^{3}$. Jej bogata historia sprawiła, że przez wieki Kefalonia była obszarem przenikania wielu kultur - krzyżowały się tu wpływy helleńskie, rzymskie, bizantyńskie, normańskie, weneckie, francuskie, tureckie, brytyjskie i nowogreckie (Bruns 1995; Freely 2008). Wskutek wspomnianych trzęsień ziemi, wyspa utraciła część swoich znakomitych zabytków; zachowane artefakty otaczane są opieką mieszkańców wyspy, którzy budują wokół nich swoje opowieści i swoją tożsamość.

\section{Cel i metodologia badań}

Pilotażowe badania etnograficzne na Kefalonii odbyły się w dniach 6-17 sierpnia 2015 roku przy okazji ekspedycji wołoskich, jakie od roku 2015 prowadzę w różnych krajach Europy w ramach grantu NPRH Wolosi w europejskiej i polskiej przestrzeni kulturowej. Historia, migracje, dziedzictwo kulturowe, a także wieloletnich porównawczych badań etnograficznych dotyczących prawosławnych miejsc kultu religijnego w regionach bizantyńsko-słowiańskich pograniczy. Celem moich badań było tylko

mniejszościowych, i legitymizowane przez różnego typu organizacje, w tym UNESCO i tworzone przez nią listy. Niezwykle istotna dla tego dziedzictwa jest odgórna, tworzona przez różne instytucjonalne podmioty narracja, nierzadko też ideologia narzucana m.in. przez władze i polityków oraz organizacje polityczne danego państwa, a także przez grupy religijne i kościoły, stowarzyszenia, zideologizowane ruchy regionalne itp. Z dziedzictwem tym łączy się też zazwyczaj promocja, mająca na celu jego upowszechnienie i zainteresowanie nim jak najszerszych kręgów społecznych w kraju i za granicą. Przeciwieństwem dziedzictwa mainstreamowego jest według mnie dziedzictwo naturalne (undergroundowe), tworzone przez społeczności lokalne lub przez indywidualności, które nie ulegają presji większości, nierzadko też marginalizowane przez zarządzających, m.in. z tego względu, że właściciele owego dziedzictwa naturalnego nie są dostatecznie bądź w ogóle zainteresowani szerszym nagłaśnianiem czy promowaniem swoich dokonań.

${ }^{2}$ Oficjalna nazwa wyspy w języku polskim to Kefalinia, jednak w polskiej literaturze przedmiotu częściej używa się nazwy zwyczajowej Kefalonia. W artykule używam obu nazw wymiennie.

${ }^{3}$ Ze względu na warunki klimatyczne wyspy, a także warunki sejsmograficzne i bezrobocie poza sezonem letnim, część autochtonicznych mieszkańców wyspy posiada obecnie swoje domy na kontynencie, a na wyspę przybywa okresowo w miesiącach letnich. 
wstępne rozpoznanie miejsc związanych z dziedzictwem kulturowym wyspy, a w szczególności miejsc prawosławnego kultu religijnego, które z jednej strony mogą zostać związane z etnosem wołoskim, z drugiej - wykorzystane w porównawczych badaniach na temat kultu ikon i sakralnych przestrzeni. Chciałam odpowiedzieć na pytanie, czy na wyspie znajdują się przestrzenie hierofaniczne (Mircea Eliade) i hierotopiczne (Aleksander Lidov), nasycone według wyobrażeń mieszkańców wyspy specjalną mocą i wynikającą stąd specjalną kreacją otoczenia (Eliade 1993a; Lidov 2006). Połączenie terminów utworzonych przez obu badaczy było dla mnie szczególnie ważne, bowiem dostrzegam ich podobieństwo i wzajemne związki. Hierofania (objawienie świętości) zakłada twórczą obecność sacrum w ludzkiej przestrzeni - powstaje poprzez wkroczenie boskości w cudowny i niespodziewany sposób pojawiającej się w ludzkim świecie, kładzie też nacisk na transcendentny charakter wydarzenia (Eliade 1993a; b: 7-37). Hierotopia (święte miejsce) to ludzka odpowiedź na hierofanię, polegająca na specjalnej twórczej kreacji przestrzeni, w której doszło do objawienia. Obie dotyczą wyobrażeń określonej grupy osób, która przekształca przestrzeń, w której doszło do objawienia (Lidov 2009). O hierotopii miejsca decyduje przede wszystkim warstwa wierzeniowa i wynikająca z niej „realizacja przestrzeni”, która zbudowana jest z wielu elementów i religijnych „gadżetów”: architektury, światła, obrazu, barw, roślin (kwiatów, ziół), świec i ich blasku, śpiewu, rytuałów i praktyk kultowych charakterystycznych dla określonego wyznania (np. pokłony, żegnanie się, a nawet przynoszone przez wiernych pożywienie). Moim zdaniem hierofania i hierotopia wchodzą we wzajemne relacje, bowiem wtargnięcie sacrum w ludzki świat zawsze pociąga za sobą odpowiedź człowieka, który w specyficzny sposób wartościuje odtąd przestrzeń objawienia. Z punktu widzenia określonej społeczności, może to być zarówno wartościowanie pozytywne (np. budowa obiektów kultu religijnego ze specjalną kreacją zewnętrznej i wewnętrznej przestrzeni przez jej wyznawców), jak i negatywne (np. zamykanie dostępu i niszczenie przestrzeni objawienia przez przeciwników określonego kultu). Jeżeli odpowiedź na podane wyżej pytania brzmi „tak”, należy zastanowić się, jakie wątki i motywy pojawiają się w wierzeniach dotyczących początków owych miejsc, cudownych ikon, niezwykłych wydarzeń czy też świętych postaci z nimi związanych; i dalej: jak zorganizowana jest w wymiarze horyzontalnym i wertykalnym przestrzeń w miejscach kultu religijnego Kefalończyków?

Poszukiwałam również artefaktów (relikwii, kapliczek, ruin), które w hiereotypicznej lokalnej przestrzeni posiadają status cudownych, związanych z nimi narracji, które chciałam porównać z przykładami znanymi mi z innych obszarów ortodoksji. Interesowało mnie, czy artefakty umieszczone w przestrzeni nawiązują też w jakiś sposób do wydarzeń, 
którym nadano miano sakralnych w narracjach Kefalończyków. Obecność podobnych artefaktów jakby w symboliczny sposób rozciągała ową przestrzeń tak, że sięga ona poza ziemskie ramy i czas. Powoduje to kolejny efekt - artefakty w zbudowanej hierotopii oddziałują ponownie w specyficzny sposób na człowieka, pozwalając mu wyjść poza granice zwykłego, codziennego postrzegania. Człowiek wchodzi z nimi w relację, „, działa wewnątrz artefaktu", staje się współtwórcą jego historii, co oznacza, że może widzieć w nim coś, co wykracza poza zwyczajowe poznanie. Wierny, poddany działaniu wielu zmysłów, zmieniających się w przestrzeni form widzi to, co umyka codziennemu spojrzeniu (Kocój 2015). Tak rodzi się relacja między człowiekiem a przestrzenią, pozwalająca badaczom odkrywać świat skomplikowanych relacji z sacrum, nie zawsze werbalizowanych.

Ponadto podczas badań zadałam sobie pytania o to, czy narracje dotyczące kultu świętych postaci otaczających opieką wyspę oraz cudownych ikon, z którymi łączą się niezwykłe lokalne wierzenia, uzależnione są od zjawisk związanych z żywiołami nawiedzającymi wyspę oraz jakie elementy, wątki i motywy pojawiają się w owych narracjach?

Przyjęta metoda badawcza opiera się przede wszystkim na badaniach jakościowych, które jednak ze względu na pilotażowy charakter badań terenowych, a także słabą znajomość języka greckiego - konieczną w tych badaniach - nie oznaczały głębokiego wniknięcia w religijną kulturę Kefalończyków. Poza analizą tekstów związanych z tematami badawczymi wybrałam technikę wywiadów swobodnych prowadzanych w języku angielskim z przedstawicielami lokalnej społeczności. Dzięki tej technice możliwe jest „odczytanie”, czyli odkrycie i zidentyfikowanie, narracji dotyczących dziedzictwa kulturowego, jak również odsłonięcie świata ludzkich wyobrażeń tworzących rodzaj przednaukowej wiedzy lokalnych społeczności (Kaufmann 2010). Zastosowałam także w przestrzeni hierotopicznej obserwację jawną oraz ukrytą. Pozwala ona przyjrzeć się przede wszystkim sferze wizualnej i behawioralnej dziedzictwa kulturowego. Dzięki niej zgromadziłam odpowiednią dokumentację fotograficzną i dokonałam wstępnej interpretacji materiału wizualnego. Podczas badań wykonano około 300 zdjęć ilustrujących obiekty dziedzictwa kulturowego oraz przestrzeni hierotopicznej, poszczególne artefakty, jak również specyficzne „osobliwości” z nimi związane ${ }^{4}$. Poszukując źródeł dotyczących religijnego dziedzictwa Kefalonii prowadziłam też badania w internecie, wykorzystując media społecznościowe (Facebook) oraz blogi i portale religijne.

\footnotetext{
${ }^{4} \mathrm{~W}$ badaniach towarzyszyła mi moja córka Karolina, która jest autorką znacznej części fotografii z Kefalonii.
} 


\section{Hierotopia wyspy Kefalonii}

Już wstępne badania pokazały, że na Kefalonii istnieje kilka ważnych miejsc kultu religijnego związanych z mitologiczną historią wyspy. Mimo że wyspa podzielona jest przez administrację religijną na dwa okręgi: Argostoli-Sami (północna część) oraz Luxouri (południowa część) (Brief Pilgrimative Guide of Holy... 1997), wierni w religijnym kulcie nie uwzględniają takiego podziału - do najważniejszych przestrzeni hierotopicznych pielgrzymują mieszkańcy całej wyspy, nawet ci z najbardziej oddalonych miejsc. Hierotopia miejsc kultu religijnego Kefalonii kreowana jest, z jednej strony, poprzez obecność takich samych wątków i motywów, jakie łączą się z historią miejsc świętych w całym prawosławiu, z drugiej zaś strony - lokalnie, przez specyfikę wyspy i jej dzieje związane z morzem i trzęsieniami ziemi.

Do najważniejszych świętych miejsc w wyobrażeniach religijnych Kefalończyków

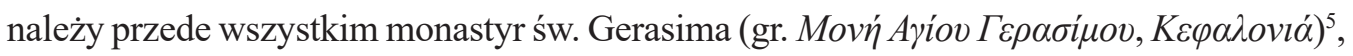
znajdujący się w środku wyspy, na tzw. płaskowyżu Omala - jedna z najstarszych świątyń i jeden z najważniejszych zabytków na Kefalonii ${ }^{6}$. Ufundowany w XVI wieku (około 1560 roku) na miejscu zrujnowanej kaplicy Wniebowstąpienia Pańskiego przez mnicha ascetę św. Gerasimosa Nowego Ascetę, który po licznych pielgrzymkach do największych ośrodków kultu religijnego w bizantyńskim świecie (Jerozolima, Stambuł, Góra Atos, Jordania, Zakynthos) zdecydował o wyborze Kefalonii na miejsce swego zamieszkania, pełni obecnie funkcję specyficznego „środka świata” w sakralnej wyobraźni Kefalończyków (The Synaxarion... 1998). Przejawem tego są liczne indywidualne pielgrzymki wiernych z wyspy i kontynentu, zachowania religijne podkreślające charakter tego miejsca, gesty wotywne, a także nazwy nadane tej przestrzeni, nawiązujące do wyobrażeń o religijnym środku świata - axis mundi (np. Nowa Jerozolima). Od wielu wieków św. Gerasim uważany jest za patrona wyspy, władającego nad złymi siłami, demonami, potrafiącego uleczyć z rozmaitych chorób. Jego święto przypada 16 sierpnia (dzień po wielkim prawosławnym święcie Zaśnięcia Bogurodzicy oraz dzień po śmierci świętego, która nastąpiła 15 sierpnia 1577 roku) oraz - po raz drugi - 20 października (Brief Pilgrimative Guide of Holy... 1997: 15). Hierotopia zbudowana jest na pamięci o świętym, a znakiem jego postaci stają się artefakty materialne zarówno na zewnątrz monastyru, jak i w jego wnętrzu. W narracjach lokalnych przestrzeń monastyru przedstawiana jest jako miejsce odosobnienia, gdzie mniszki żyją współcześnie w harmonii z przyrodą i w ciszy, a przybywający tu

\footnotetext{
${ }^{5}$ Św. Gerasim z Kefalonii urodził się w Trikali Koryntu w 1506 r., studiował w Zakintos, w tym czasie najważniejszym ośrodku edukacyjnym. Początkowo żył jako pustelnik w jaskini w rejonie Lassi w Argostoli, a następnie ok. 1560 r. założył monastyr w Omala.

${ }^{6}$ Obecnie jest to monastyr żeński - opiekę nad nim sprawują prawosławne mniszki.
} 
ze świata zewnętrznego wierni mogą zakosztować religijnego raju, w którym przejawia się też specyficzna moc św. Gerasima. Badania pokazały, że pierwszym elementem takiej kreacji jest sam monastyr wraz z jego otoczeniem - położony z dala od wioski, pełen śladów obecności świętego. Wewnątrz świątyni, obok ikonostasu, znajduje się ogromnych rozmiarów relikwiarz z jego ciałem, ozdobiony ikoną przedstawiającą zaśnięcie ascety oraz sceny z jego życia. Ułożenie relikwiarza, który prawie dotyka ikonostasu, przywodzi na myśl symboliczne „przedłużenie” świętości ołtarza w prezbiterium - w wierzeniach prawosławnych zetknięcie się z tą przestrzenią przenosi jego świętość na artefakty, które same stają się w ten sposób uświęcone, co ma swoje odległe korzenie w tradycji żydowskiej, związanej z miejscem tzw. Świętym Świętych w Przybytku Mojżeszowym wykonanym na pustyni według zaleceń samego Jahwe, a następnie w jednej z części Świątyni Jerozolimskiej (Pismo Święte Starego i Nowego Testamentu. Biblia Tysiąclecia, Wj 26,1-19; $1 \mathrm{Krl}$ 8,1-16). Same relikwie świętego otoczone są kultem przez Kefalończyków, którzy pielgrzymują do nich, by podziękować za wymodlone łaski oraz zanosić prośby o pomoc i uzdrowienia. Służą temu specjalne gesty - dotykanie dłońmi relikwiarza, pocałunki, żegnanie się, pokłony, składanie w darze roślin.

Wierni gromadzą się w monastyrze już w dniu święta Zaśnięcia Bogurodzicy oraz w wigilię dnia św. Gerasima. Wielu z nich przybywa tu także już 9 sierpnia, traktując nadchodzące dni aż do uroczystości ku czci św. Gerasima jako czas sakralny. 16 sierpnia odbywa się procesja z relikwiami świętego przenoszonymi do ogromnego drzewa - platanu, znajdującego się kilkaset metrów od monastyru. Do świątyni docierają tysiące wiernych z wyspy i kontynentu, plac wypełniają straż i honorowa asysta oraz zespoły grające muzykę podczas procesji. Procesja idąca $\mathrm{z}$ relikwiami świętego nabiera też znaczenia symbolicznego. Przedstawia ona niejako relację między świętym a naturą - podczas drogi udzielają oni sobie wzajemnie mocy (natura Gerasimowi, a Gerasim naturze), którą potem przekazują wiernym. Tradycja lokalna głosi, że drzewo zasadził św. Gerasim. Kefalończycy wierzą, że odpoczywając w jego cieniu czerpią moc $\mathrm{z}$ otaczającej przestrzeni i z samej rośliny. Na trasie procesji opętani przez demony kładą się na ziemi, pod przenoszonym przez duchownych i wiernych relikwiarzem tak, by dotykał ich ciała (Håland 2016). Kolejne osoby tworzą symboliczny łańcuch z ciał - na nogach leżących kolejni chorzy kładą swoje głowy. Wielu z nich krzyczy, mówi w niezrozumiałych językach, żegna się i płacze. Wędrówka relikwii przypomina odnowienie czasu i przestrzeni, a wraz z nimi odpędzenie chorób i złych sił, które zaatakowały prawosławnych wiernych

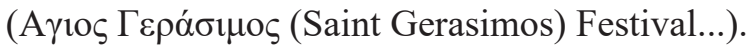

Świętość miejsca i postaci wzmocniona zostaje także wertykalnie przez znajdującą się w monastyrze pod ziemią pustelnię, do której wchodzi się obecnie ze środka cerkwi, 
po pionowej metalowej drabinie o długości 3 metrów. Surowa, wykuta w kamieniu, składa się z dwóch pomieszczeń, przy czym do drugiego - niewielkiej sali z wyrytymi na ścianach krzyżami - prowadzi bardzo niskie i wąskie kamienne przejście. Znalezienie się w tym miejscu jest dla pielgrzymów, pragnących doświadczyć sakralności przestrzeni, etapem podążania śladami pustelnika, przypomina też o ascezie jako podstawie jego trybu życia. Przekroczenie wąskiego przejścia wiąże się też z koniecznością przełamania własnego lęku, bowiem ma się wrażenie wstępowania do „odmiennej” od codziennej przestrzeni. Narracje lokalne dają wyraz przekonaniu, że w tym miejscu jeszcze i dziś dokonują się cuda ${ }^{7}$. Wciąż żywa jest wiara, iż wejście w ową przestrzeń przyniesie uzdrowienie, zaowocuje uzdrowieniem, odzyskaniem sił oraz wszelkiego rodzaju błogosławieństwa. Cudowna, sakralna przestrzeń uwalnia też, w wyobrażeniach ludzi, od wszelkich słabości, pozwala przekraczać naturalne bariery cielesności i doświadczać cudów:

w monastyrze św. Gerasima są takie pustelnie, tam jest takie wąskie przejście, widziałam wielu ludzi, którzy tam przechodzą, różnej grubości, bardzo, bardzo grubych, o takich, i przechodzili bez problemu, to cud. Normalnie nie mogliby przejść, bo są tacy grubi, ale św. Gerasim czyni wiele cudów, tam wydarza się wiele cudów ${ }^{8}$.

Badaniami objęłam także kolejne bardzo ważne hierotopiczne miejsce kultu religijnego na Kefalonii - znajdujący się na południu wyspy, w okręgu Argostori, monastyr Matki Bożej Lagouvarda w Markopoulo (Klitsenko). Moje badania polegały tu przede wszystkim na obserwacji uczestniczącej prowadzonej w dniu 15 sierpnia 2016 roku, podczas święta Zaśnięcia Bogurodzicy. Sama przestrzeń świątyni zmienia się w tym czasie znacząco - wypełniają ją mieszkańcy Kefalonii i turyści przybywający do monastyru, aby doświadczyć łask płynących od znajdującej się tu ikony Matki Bożej i zobaczyć „cud z wężami”. Turyści dowiadują się o tym wydarzeniu przede wszystkim od Kefalończyków, jak również z przewodników turystycznych i stron internetowych, które coraz częściej zawierają informację o tym święcie, co powoduje, że w dni świąteczne w monastyrze panuje ogromny tłok.

Okoliczności powstania wspomnianego monastyru nie są jasne, nie zachowały się bowiem źródła historyczne dotyczące jego dziejów. Miejscowa tradycja głosi, że przestrzeń, w której został wzniesiony, ma sakralny charakter, a źródłem jej mocy jest sama budowla oraz cudowna ikona Bogurodzicy zwana Panagia Lagouvarda (Władczyni Węży, Królowa Węży) lub Panagia Fidoussa (Phidousa - Władczyni Węży, Królowa Węży), z wężami namalowanymi też na samej postaci Matki Bożej. W 1705 roku monastyr

\footnotetext{
${ }^{7}$ Badania terenowe, obserwacja uczestnicząca, monastyr św. Gerasima, Omala, Kefalonia, 8 sierpnia 2015 r. Materiały terenowe zgromadzone podczas badań znajdują się w archiwum autorki.

${ }^{8}$ Badania terenowe, wywiad, Kounopetra Lixouri, 11 sierpnia 2015 r., kobieta, mieszkanka wyspy.
} 
zniszczyli piraci lub, według innych narracji, Turcy (Ortodoxwiki; Håland 2011), a mniszki zostały uwięzione $-z$ tej opresji miały zostać uwolnione dzięki modlitwom zanoszonym do Matki Bożej, która wysłuchała ich próśb i przemieniła w węże, które ukryły się w ruinach zniszczonej świątyni. Przemiana przyczyniła się do ocalenia mniszek (zob. Church of Virgin Mary Lagouvarda in Markopoulo...). Monastyr częściowo spłonął w 1945 roku, a potem uległ całkowitemu zniszczeniu podczas trzęsienia ziemi na Kefalonii w roku $1953^{9}$.

W dniu święta Zaśnięcia Bogurodzicy ikona Panagii staje się najważniejszym elementem hierotopii w monastyrze - ustawiana jest na specjalnym analogionie pośrodku cerkwi. Zostaje on nakryty białym obrusem ozdobionym haftem przedstawiającym złoty krzyż i winorośl; w wazonie obok ikony kładzie się białe lilie. Przy analogionie umieszczany jest stół również nakryty białym obrusem, a na nim akwarium z małymi wężami. Ikona staje się ośrodkiem całego kultu i niezwykłych wydarzeń się tu odbywających - tzw. festiwalu węży, które według lokalnych wierzeń, pomiędzy świętami Przemienienia Pańskiego (6 sierpnia) i Zaśnięcia Bogurodzicy (15 sierpnia), wychodzą z ziemi i przybywają w przestrzeń świątyni. Są to tzw. kocie węże, należące do gatunku Telescopus fallax (lub podgatunku Telescopus fallax pallidus) (The IUCN Red List of Threatened Species) - charakteryzują się niewielkimi rozmiarami i łagodnym usposobieniem, na głowie mają ciemny ornament, który przez wiernych interpretowany jest jako kształt krzyża. Według narracji lokalnych, potwierdzonych kręconymi tu filmami umieszczanymi w sieci, ich zachowanie jest szczególne - wpełzają pod ikonę Bogurodzicy, oplatają się wokół krzyża, towarzyszą księdzu w celebrowaniu liturgii, usadawiając się na ewangelii (Sanidopoulos 2011a). Wierni trzymają je w dłoniach, kładą na twarzy i szyi, oplatają nimi dłonie i ciało (zob filmy: Mysterious Virgin Mary’s Sacred Snakes of Kefalonia (Greek News); Orthodox Miracle Snakes of the Theotokos; Şerpii Maicii Domnului; Minune!!! Şerpii vin an de an la Icoana Maicii Domnului...). U podstaw tych zachowań, w swej istocie magicznych i znanych wciąż w różnych regionach Europy, leży przekonanie, że poprzez kontakt z określonym zwierzęciem lub artefaktem, przenosi się na osobę część jego cech (m.in. siłę, odwagę, zdolności odpędzania chorób). Mieszkańcy wyspy wierzą, że nieobecność węży podczas święta Zaśnięcia związana jest z przekazywanymi przez nie znakami-wiadomościami: w ten sposób czuwają nad Kefalończykami, ostrzegając ich przed niebezpieczeństwami ze strony żywiołów czy obcych. Wśród Kefalończyków panuje bowiem przekonanie, że w czasie zagrożeń lub zawirowań historycznych węże pozostają w ukryciu. Tak było na przykład w roku 1923, kiedy patriarcha ekumeniczny Melecjusz IV zwołał do Konstantynopola konferencję (zwaną panortodoksyjnym

\footnotetext{
${ }^{9}$ Badania terenowe, wywiad, Markopoulo, Kefalonia, 15 sierpnia 2015 r., kobieta, mniszka monastyru.
} 
kongresem), na której postanowiono zrezygnować z dotychczas stosowanego w Kościele prawosławnym kalendarza juliańskiego i przyjąć kalendarz gregoriański (Kocój 2013: 47-49). Dla wielu wiernych z różnych regionów, w tym dla Kefalończyków, był to moment zagrożenia, ponieważ zmieniał tradycję mierzenia czasu obowiązującą od pokoleń. W owym roku węże nie pojawiły się w cerkwi w Markopoulo w dniu, kiedy przypadało święto według starego stylu; zobaczono je podczas obchodów święta według nowego stylu, co odczytane zostało przez prawosławnych mieszkańców Kefalonii jako znak nakazujący im przyjęcie kalendarza gregoriańskiego (Sanidopoulos 2011b). W opowieściach lokalnych pojawia się też wątek o wydarzeniach z drugiej wojny światowej, kiedy na wyspie toczyły się walki niemiecko-włoskie. Nieobecność węży w monastyrze w 1944 roku odczytana została post factum jako zapowiedź eksterminacji dokonanej przez Niemców:

węże kiedyś były liczniejsze niż dziś, szczególnie przed drugą wojną światową, nie wiem dlaczego. W niektóre lata nie pojawiają się wcale. To są złe lata, tak jak w tym roku, kiedy Niemcy dokonali eksterminacji włoskich żołnierzy, chociaż wcześniej byli ich sojusznikami. To zawsze jest zły znak, kiedy węże nie pojawiają się (Sanidopoulos 2011a).

Narracje w podobnym duchu są przywoływane przy opisach trzęsienia ziemi z 1953 (Sanidopoulos 2009) oraz z 2014 roku:

\begin{abstract}
widziałam węże, są małe, cienkie, mają na głowie krzyż. Wychodzą prawie w każdym roku. Ale w zeszłym roku nie wyszły. U nas było trzęsienie ziemi, ziemia zatrzęsła się bardzo mocno, to był taki wstrząs, nagle, silny. Tylko u nas, epicentrum było za Lixuri, inne części Kefalonii nie przeżyły wtedy trzęsienia ziemi. Nie było dużych zniszczeń. Mówią, że jak ma być trzęsienie ziemi, to węże nie wychodzą. Węże mnisi trzymają też w takim specjalnym naczyniu, trzy, cztery węże trzymają ${ }^{10}$.
\end{abstract}

Badania pokazały, że na Kefalonii istnieją także inne, bardzo ważne w lokalnym kulcie miejsca hierofaniczne. $\mathrm{W}$ ich mitycznej historii pojawia się po raz kolejny odwołanie do specyficznego położenia i warunków naturalnych. W wyobrażeniach mieszkańców Kefalonii ich przestrzeń nasycona jest legendami, których treść dotyczy przybywających tu obcych żeglarzy, jak i żyjących tu niegdyś mnichów urastających do rangi lokalnych „świętych” (niekanonizowanych oficjalnie). W narracjach lokalnych łączą się one w wielu przypadkach z historiami powstania różnych monastyrów, które z kolei są często powiązane z cudowną opieką Matki Bożej nad mieszkańcami wyspy. Objawia ona swą moc przede wszystkim poprzez pomoc podczas ataku żywiołów, zwłaszcza trzęsień ziemi, a także w trakcie podróży morskich. Jednym z takich miejsc jest monastyr Zwiastowania Matce Bożej w Kipouria, położony na jednym z zachodnich klifów wyspy, około 15 kilometrów od miejscowości Lixouri. Wybudowany w 1759 roku przez mnicha Chrisanthosa

${ }^{10}$ Badania terenowe, wywiad, Kounopetra Lixouri, 11 sierpnia 2015 r., kobieta, mieszkanka wyspy. 
Petropoulosa, szybko stał się centrum życia religijnego wyspy, gromadząc w swych murach wiele znakomitych ojców duchowych (Brief Pilgrimative Guide of Holy... 1997: 91). Pełnili oni ważną rolę w edukacji mieszkańców Kefalonii, prowadząc w monastyrze szkołę dla dziewcząt i pełniąc posługę starców wśród prawosławnych wiernych, którzy przybywali tu z prośbą o tzw. słowo, czyli duchową poradę. Został w znacznej części zniszczony podczas trzęsienia ziemi w 1953 roku.

O tym, że dla mieszkańców Kefalonii miejsce to jest znaczące w hierotopii wyspy, decydują dwa powody: znajdujące się tu religijne artefakty, których początki noszą w wyobrażeniach prawosławnych znamiona cudownych, oraz obecność w przeszłości świętych ojców (starców) zamieszkujących tę przestrzeń i naznaczających ją swoją niezwykłą wiarą. Do najważniejszych artefaktów budujących hierotopię należy świątynia z okalającym ją murem i otwartymi krużgankami. W cerkwi, blisko ikonostasu, w specjalnym drewnianych kiwocie ${ }^{11}$, znajduje się ikona Zwiastowania Matce Bożej, która w przekonaniu wiernych posiada niezwykłą moc. Sakralną przestrzeń wzmacnia też znajdujący się obok ikony relikwiarz, drewniany i ozdobiony wizerunkami aniołów oraz tkaniną w kolorze bordowym z wyhaftowanym cekinami krzyżem, zawierający fragment drzewa Krzyża Świętego przekazany mnichom monastyru przez rosyjskiego kniazia Włodzimierza Andriejewicza Dołgorukowa (Владимир Андреевич Долгоруков). W 1862 roku w czasie walk rosyjsko-tureckich kniaź został za ich sprawą w cudowny sposób ocalony. Podczas potężnej burzy na morzu ujrzał ogromny jaśniejący krzyż ponad monastyrem położonym na skałach i skierował tam statek. Mnisi uratowali załogę i zaoferowali jej schronienie. W dowód wdzięczności kniaź po powrocie do Rosji wysłał mnichom relikwie Krzyża Świętego, przedstawiając jednocześnie całe wydarzenie na piśmie. Podarowane przez niego artefakty eksponowane są w specjalnych gablotach, dostępnych dla zwiedzających, znajdujących się w wyznaczonym dla nich pomieszczeniu w krużgankach monastyru. Opowieści o tym wydarzeniu są do dziś żywe wśród mieszkańców Kefalonii, ulegają też swoistym lokalnym przekształceniom, łącząc się z legendami miejsca dotyczącymi postaci niezwykłych mnichów mieszkających w monastyrze:

To teraz monastyr z jednym mnichem, sam został w całym monastyrze. Wcześniej mieszkał tu też jeden mnich, wszyscy do niego przybywali, ludzie bardzo go szanowali, pomagał im, codziennie spał w innym miejscu świątyni, wyplatał krzyżyki i nosił ze sobą cały czas fragment Świętego Krzyża, który dostał z Rosji, w podzięce za uratowanie syna rosyjskiego księcia. Płynęły statki, były duże fale, ten kniaź ujrzał krzyż na monastyrze i uratował się, przypłynął do monastyru. Potem w podziękowaniu, jak do Rosji wrócił, przysłał fragment Krzyża, niewielki kawałek Krzyża Świętego ${ }^{12}$.

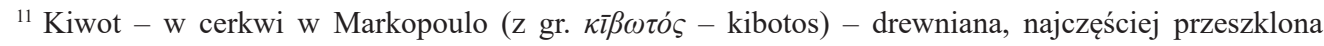
i ozdobna rama lub płytka szafka, w której umieszcza się obrazy kultu religijnego, znajdująca się zarówno w świątyniach rytów wschodnich, jak i w domach wiernych.

${ }^{12}$ Badania terenowe, wywiad, 11 sierpnia 2015 r., Kounopetra Lixouri, mężczyzna, mieszkaniec wyspy.
} 
W relikwiarzu znajdują się też relikwie św. Dymitra Wielkiego Męczennika oraz św. Paraskiewy Męczennicy (z Ikonium), wzmacniając w wyobrażeniach wiernych świętość przestrzeni.

Innym hierotopicznym miejscem na Kefalonii jest monaster Zaśnięcia Bogurodzicy w Koronato, w zachodniej części wyspy. Jego początki wiążą się w tradycji miejsca z cudowną ikoną Bogurodzicy, którą przywiózł w XV wieku na Kefalonię miejscowy arystokrata Leon Plykalas, fundując tu dla niej małą cerkiew. W kolejnych wiekach budowla została zniszczona, prawdopodobnie przez trzęsienie ziemi. Wspomnianą ikonę odnalazł pasterz z wioski Polykalata, który przy wypasie, podczas wędrówki w poszukiwaniu wody, dotarł do ruin świątyni. W jej religijnej historii odnajdujemy motyw wyboru miejsca przez Matkę Bożą „uosobioną na ikonie” na swoje zamieszkanie i związaną z nim wędrówkę artefaktu, znany w wielu regionach chrześcijaństwa. Według wierzeń Kefalończyków, na rosnącym nieopodal drzewie figowym, pasterz zauważył „malowidło” i mały krzyż. Postanowił zabrać te przedmioty ze sobą, jednak próby ściągnięcia ich z drzewa okazały się bezowocne, jako że w niewyjaśniony sposób powracały one na miejsce, w którym pasterz je zobaczył. Dowiedziawszy się o tym, mieszkańcy wioski postanowili wznieść tam świątynię. Oryginalna ikona Bogurodzicy Koroniotissa zaginęła - obecnie w cerkwi znajduje się jej kopia, która posiada status cudownej. Wizerunek Matki Bożej słynie z płaczu. Po raz pierwszy dostrzeżono to zjawisko w styczniu 1807 roku - kiedy podczas trzęsienia ziemi ikona została odnaleziona na ziemi, w oczach Matki Bożej pojawiły się łzy (Brief Pilgrimative Guide of Holy... 1997: 73-77): ,jest tu cudowna ikona, została znaleziona na drzewie jabłkowym, tutaj, ona pomaga ludziom, Matka Boża na tej ikonie płacze, jak ma być trzęsienie ziemi, ostrzega ludzi przez trzęsieniem"13.

Kolejnym punktem hierotopicznej przestrzeni wyspy jest Kechriona z monastyrem Zaśnięcia Bogurodzicy, wybudowanym w XVIII wieku jako dar wotywny przez rodzinę Zakynthinos - trójkę żeglarzy z wyspy Zakynthos. Wyruszyli oni do Algierii; uwięzieni w tym kraju prosili Matkę Bożą o oswobodzenie, modląc się do niej w dniu święta Zaśnięcia Bogurodzicy. Zapadli w sen, podczas którego zostali w cudowny sposób przeniesieni do Kechriony, w okolice mostu znajdującego się nieopodal monastyru. Wdzięczni za ocalenie, według niektórych wariantów legendy, zostali mnichami i wybudowali w 1828 roku nową cerkiew. Znajdująca się tu ikona Bogurodzicy słynie z wielu cudów. Ma także status ikony płaczącej - według wierzeń łzy Matki Bożej mają ostrzegać wiernych przed trzęsieniem ziemi:

\footnotetext{
${ }^{13}$ Badania terenowe, wywiad, 11 sierpnia 2015 r., Kefalonia, kobieta, mieszkanka wyspy.
} 
w monastyrze jest cudowna ikona Matki Bożej, z nią związana jest taka opowieść: trzech mężczyzn zostało uwięzionych, oni byli niewolnikami, prosili o uwolnienie. Modlili się do Matki Bożej i w jakieś święto ikony Matki Bożej zostali uwolnieni, wrzucono ich do wody, zaczęły bić dzwony i oni zostali przeniesieni tu, do Kechriony, zostali uratowani przez te ikonę Matki Bożej ${ }^{14}$.

\section{Wnioski}

W wyobraźni religijnej Kefalończyków ważne miejsce zajmują wyspiarski charakter regionu oraz żywioły: morze i trzęsienia ziemi cyklicznie nawiedzające wyspę. Specyficzne warunki naturalne leżą u podstaw lokalnych legend i hierotopicznych kreacji miejsc kultu religijnego. Zdeterminowały też panteon świętych opiekunów czuwających nad wyspą: to Matka Boża otaczająca wyspę swoją opieką, do której należy ostrzeganie przed cyklicznie powracającymi tu trzęsieniami ziemi, węże ze znakiem krzyża oraz święci. Ci ostatni w wyobrażeniach wiernych, z jednej strony wybierają wyspę jako przestrzeń rajskiej szczęśliwości (topos miejsca odosobnionego, gdzie człowiek doświadcza harmonii i obecności Boga, żyjąc z dala od cywilizacji), z drugiej strony zyskują specjalne właściwości - potrafią na przykład przenosić mieszkańców wyspy w cudowny sposób przez morze, ostrzegają ich przed trzęsieniami ziemi, ratując przed nimi tych, których cechuje bogobojność i którzy zwracają się do nich z prośbą o pomoc. Ten fascynujący świat wyobrażeń mieszkańców Kefalonii, zaledwie „,dotknięty” przeze mnie w badaniach etnograficznych, pokazuje, że greckie niematerialne dziedzictwo kulturowe pełne jest archaicznych treści, które wraz z artefaktami utworzonymi tu w przeszłości, pełnią symboliczną rolę w ujawnianiu głębokich znaczeń istniejących w greckiej religijności. Wiele elementów tego dziedzictwa wskazuje zarówno na podobieństwo do znanych motywów z innych regionów prawosławia, jak również ukazuje treści specyficzne dla prawosławnych Kefalończyków żyjących na wyspie.

\section{Bibliografia}

Pismo Święte Starego i Nowego Testamentu. Biblia Tysiąclecia (1995). Poznań-Warszawa: Wydawnictwo Pallottinum

Brief Pilgrimative Guide of Holy Metropolis of Cephalonia (1997). Holy Metropolis of Cephalonia.

Bruns, H.E. (1995). Cephalonia (Cepalonia, Greece). In: S. la Boda (ed.), International Dictionary of Historic Places, vol. 3, Southern Europe (p. 136-138). Chicago: Routledge.

\footnotetext{
${ }^{14}$ Badania terenowe, wywiad, 10 sierpnia 2015 r., Kefalonia, mężczyzna, mieszkaniec wyspy.
} 
Eliade, M. (1993a). Sacrum, mit, historia (przeł. A. Tatarkiewicz). Warszawa: Państwowy Instytut Wydawniczy.

Eliade, M. (1993b). Traktat o historii religii (przeł. J. Wierusz-Kowalski). Warszawa: Państwowy Instytut Wydawniczy.

Freely, J. (2008). The Ionian Islands: Corfu, Cephalonia, Ithaka and beyond. London-New York: I.B. Tauris.

Håland, E.J. (2011). Saints and Snakes: Death, Fertility, and Healing in Modern and Ancient Greece and Italy. Performance and Spirituality, 2 (1), 111-151.

Håland, E.J. (2016). The Festival Dedicated to Agios Gerasimos a Healing Saint Fighting Demons: a Case Study. Mediterranean Review, 9 (2), 17-41.

Klitsenko, Y. Religious Fables, Folklore, Legends, and Stories. The Miracle of Snakes in Greece. Pozyskano z http://www.all-creatures.org/articles/rf-themiracleofsnakes. html.

Kaufmann, J.C. (2010). Wywiad rozumiejący (przeł. Alina Kopciak). Warszawa: Oficyna Naukowa.

Kocój, E. (2006). Świątynie, postacie, ikony. Malowane cerkwie i monastyry Bukowiny Południowej w wyobrażeniach rumuńskich. Kraków: Wydawnictwo Uniwersytetu Jagiellońskiego.

Kocój E. (2013). Pamięć starych wieków. Symbolika czasu w rumuńskim kalendarzu prawosławnym. Kraków: Wydawnictwo Uniwersytetu Jagiellońskiego.

Kocój, E. (2015). Sacrum i łzy. Fenomen płaczących ikon w wyobrażeniach religijnych w prawosławiu (wybrane zagadnienia - I). Slavica Slovaca, 50 (2), 140-156.

Lidov, A. (2006). New Jerusalems: Hierotopy and Iconography of Sacred Spaces. Moscow: Indrik.

Lidov, A. (2009). Hierotopy: Spatial Icons and Image-Paradigms in Byzantine Culture. Moscow: Theoria.

Sanidopoulos, J. (2009). Saint Gerasimos of Kefallonia and the Demons Possessed. Pozyskano z http://www.johnsanidopoulos.com/2009/10/st-gerasimos-of-kefallonia-and-demon.html.

Sanidopoulos, J. (2011a). The Annual Appearance of the Snakes of the Panaghia of Kefallonia. Pozyskano z http://www.johnsanidopoulos.com/2011/08/annual-appearance-of-snakes-of-panagia.html.

Sanidopoulos, J. (2011b). The Holy Snakes of Keffalonia and the Calendar Change of 1924. Pozyskano z http://www.johnsanidopoulos.com/2011/08/holy-snakes-of-kefallonia-and-calendar.html. 
The Synaxarion: The Lives of the Saints of the Orthodox Church (1998). Vol. 1, Introduction, September, October. Holy Convent of The Annunciation of Our Lady. Ormylia (Chalkidike). Pozyskano z http://www.gometropolis.org/orthodox-faith/ feast-days/saint-gerasimus-of-cephalonia/.

\section{Źródła internetowe}

Ortodoxwiki https://orthodoxwiki.org/Holy_Snakes

The IUCN Red List of Threatened Species http://www.iucnredlist.org/details/157258/0

\section{Źródla audiowizualne}

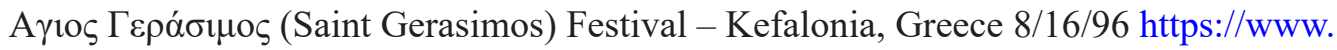
youtube.com/watch?v=kkyfHiW-Qrg

Church of Virgin Mary Lagouvarda in Markopoulo (Fidiotissa or Fidoussa) https:// greece.terrabook.com/kefalonia/page/church-virgin-mary-lagouvardamarkopoulo-fidiotissa-fidoussa

Mysterious Virgin Mary's Sacred Snakes of Kefalonia (Greek News), reż. G. Mendoros https://www.youtube.com/watch?v=LccpW44CKG4

Orthodox Miracle Snakes of the Theotokos https:/www.youtube.com/watch?v=F5Za9-uX4b8, https://www.youtube.com/watch?v=p -AOO903CZA

Şerpii Maicii Domnului https://www.youtube.com/watch?v=hDPgJykV2Cg

Minune!!! Şerpii vin an de an la Icoana Maicii Domnului iar crinii uscaţi înfloresc la Icoana Sa http://modeoflife.org/documentary-the-snakes-of-our-lady-of-markopoulokefalonia/

\section{Spis fotografii}

Fot. 1 Pustelnia w monastyrze św. Gerasima, Kefalonia, 2015; fot. K. Kocój.

Fot. 2 Ikona Panagia Lagouvarda, Markopoulo, Kefalonia, 2015; fot. K. Kocój.

Fot. 3 Monastyr Zwiastowania Matce Bożej w Kipouria, Kefalonia, 2015; fot. K. Kocój. 


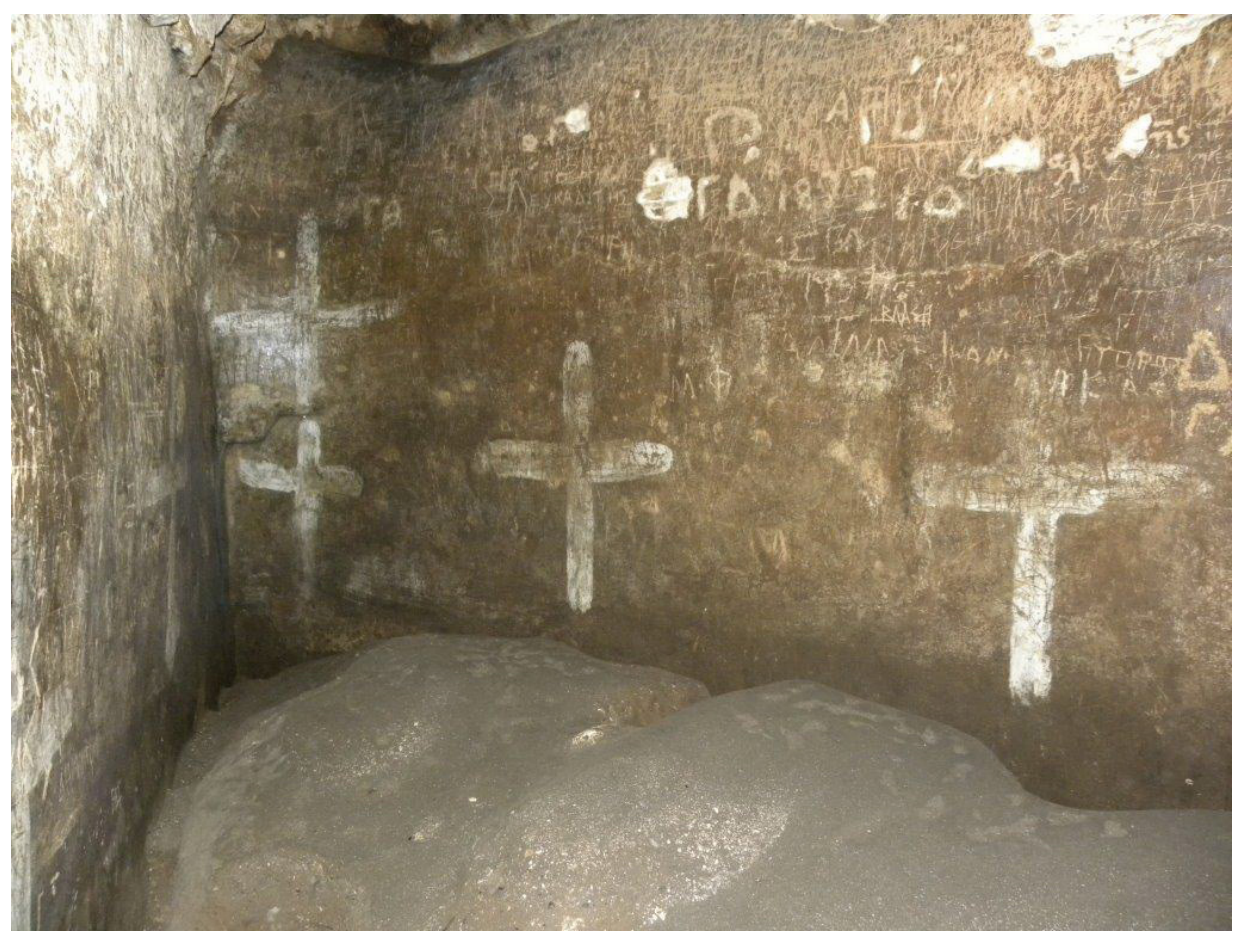

Fot. 1 Pustelnia w monastyrze św. Gerasima, Kefalonia

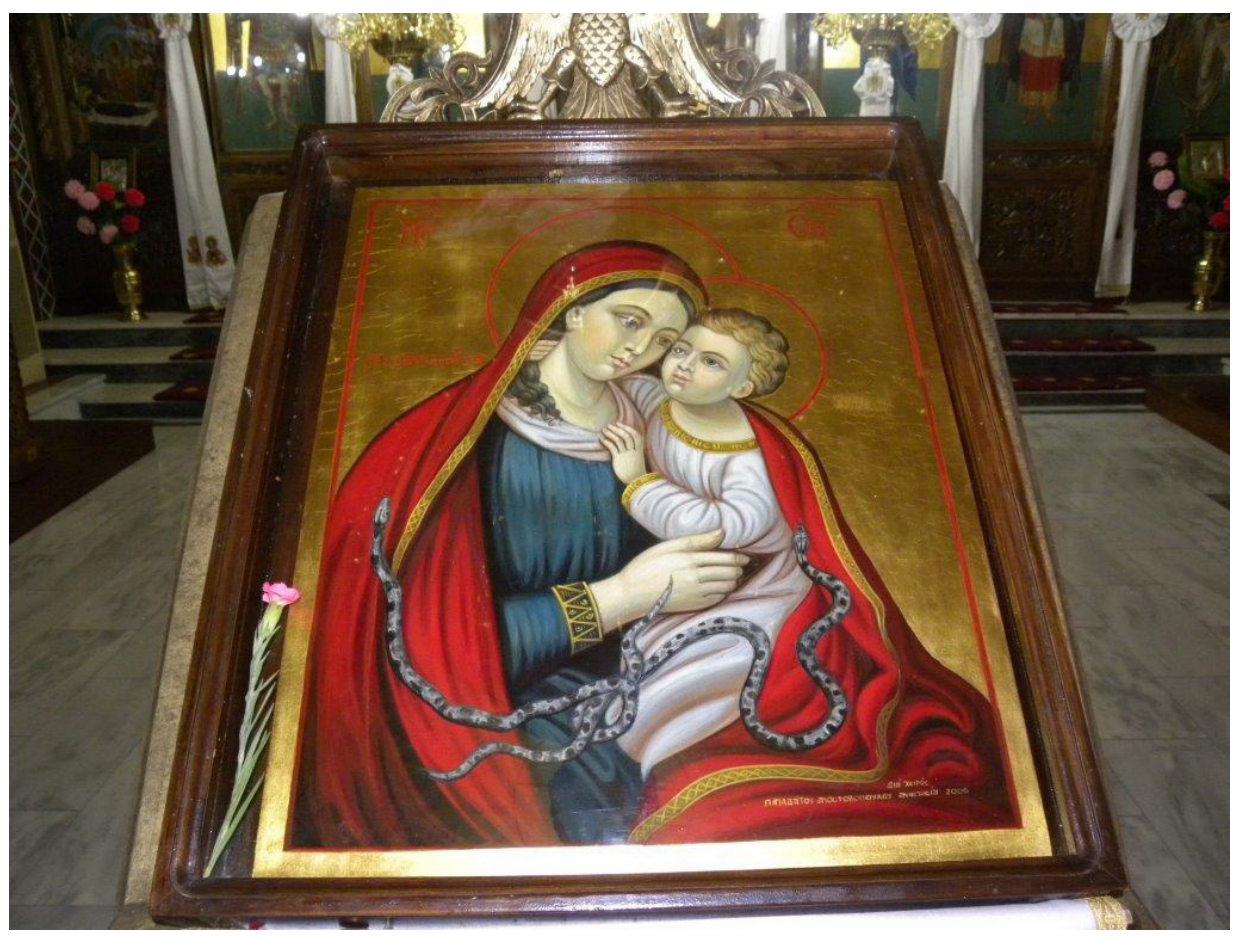

Fot. 2 Ikona Panagia Lagouvarda, Markopoulo, Kefalonia 


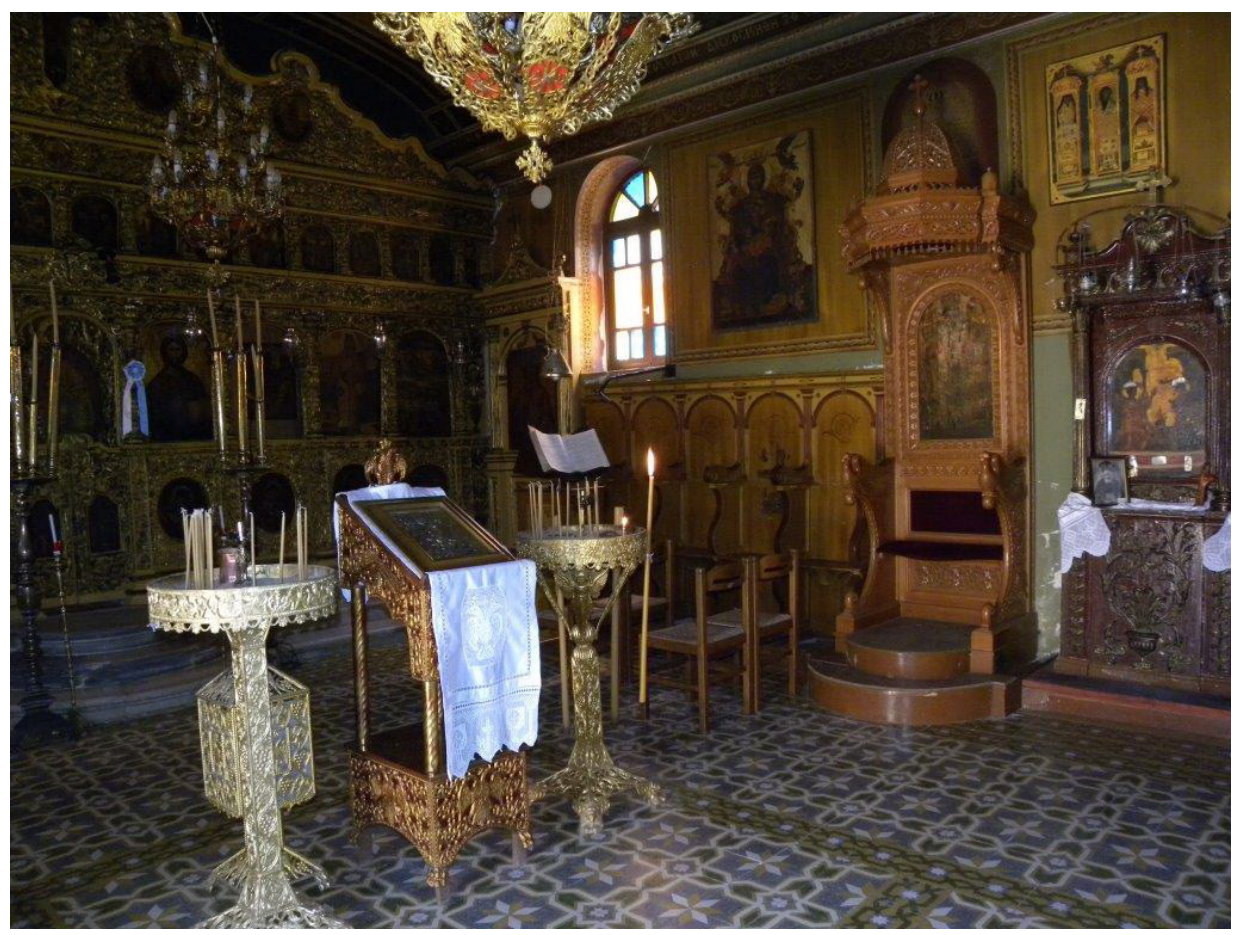

Fot. 3 Monastyr Zwiastowania Matce Bożej w Kipouria, Kefalonia 
